MAKALAH PENGANTAR MANAJEMEN MOTIVASI

DAN KEPEMIMPINAN

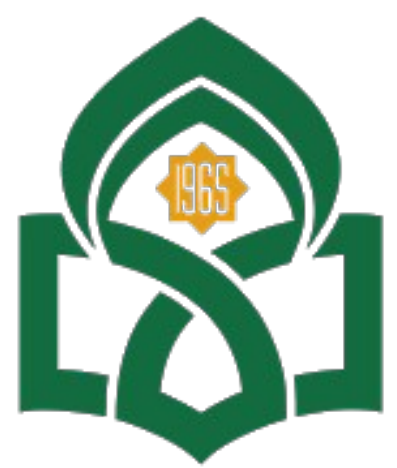

UNIVERSITAS ISLAM NEGERI

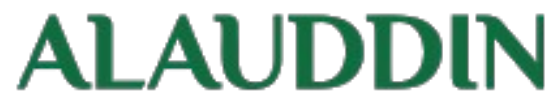

M A K A S S A R

Dosen pengampu:

Dra. Hj. Nuraeni Gani MM.

Disusun Oleh

ASRIANI

90500121113

JURUSAN PERBANKAN SYARIAH

FAKULTAS EKONOMI DAN BISNIS ISLAM

UIVERSITAS ISLAM NEGERI ALAUDDIN MAKASSAR 
KATA PENGANTAR

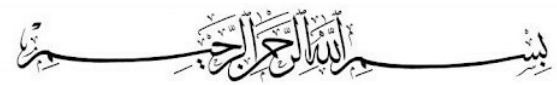

Asalamualaikum Warahmatullahi Wabarakatuh

Puji dan syukur kita panjatkan ke hadirat Allah SWT. Atas rahmat dan karunia-Nya saya dapat menyelesaikan makalah yang saya buat dengan waktu yang telah ditentukan.

Saya menyadari dalam makalah ini masih banyak terdapat kesalahan dan kurang baik dalam segi tulisan maupun kata-kata, oleh karena itu saya mohon saran dan kritiknya demi kesempurnaan makalah ini untuk kesempurnaan terutama ilmu saya.

Semoga makalah yang saya buat ini dapat bermanfaat bagi kita semua untuk kedepannya. Semoga Allah Subhanallahu wa ta'ala membalas kebaikan kalian semua. Semoga makalah ini dapat bermanfaat bagi semua pihak. Aamiin.

Wassalamualaikum WarahmatullahiWabarakatuh

Makassar, 16 Desember 2021

Penulis

ASRIANI

DAFTAR ISI

KATA PENGANTAR _ ii

DAFTAR ISI _ _ _ _ _ _ _ _ _ _ _ _ _ _ _ _ _ _ _ _ _ _ _ _ _ _ _ _ _ _ _ _ _ _

$\mathrm{BABI}$ 


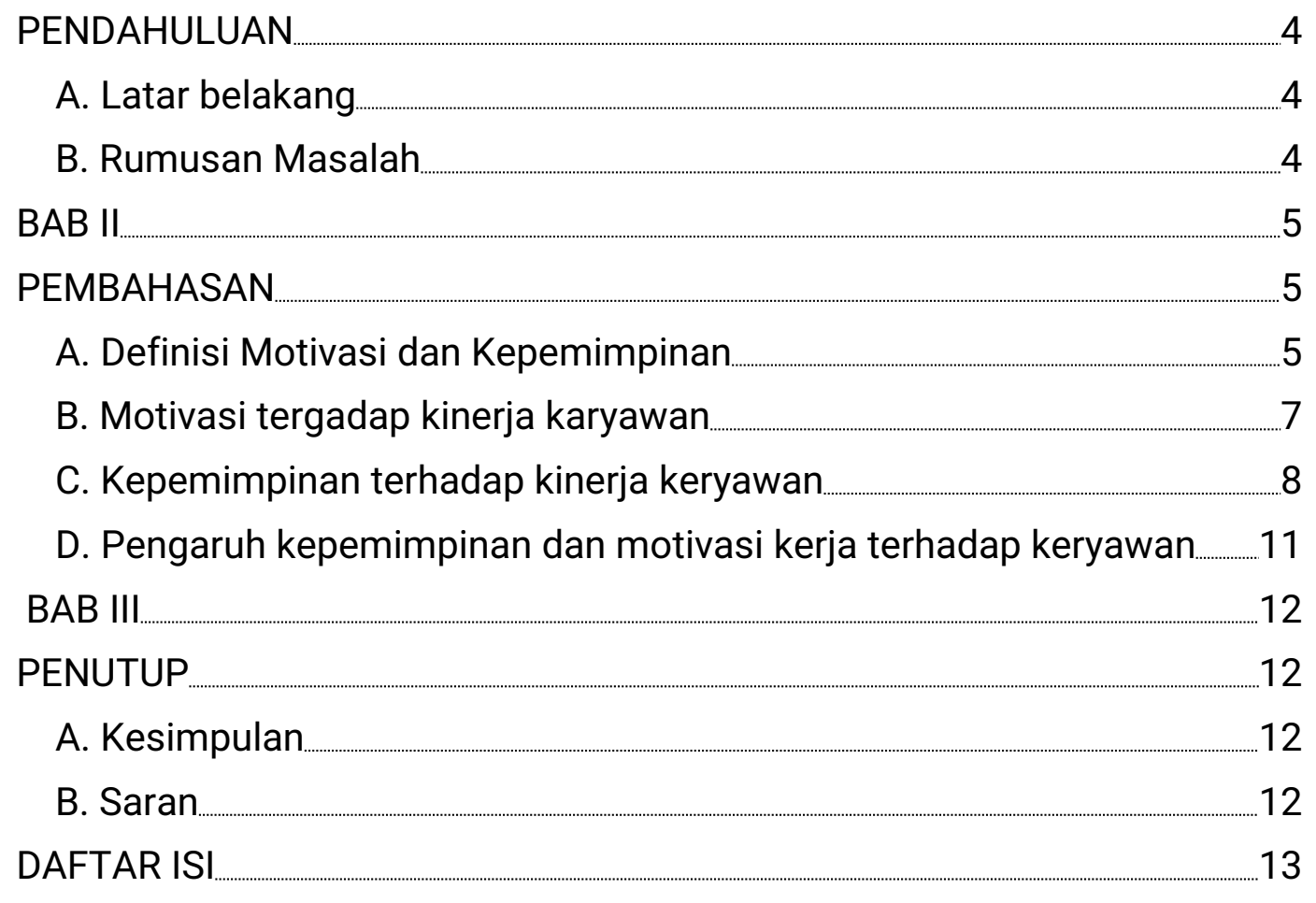


BAB I

PENDAHULUAN

\begin{abstract}
A. Latar belakang
Untuk dapat mencapai tujuan perusahaan/instansi diperlukan
\end{abstract} suatukepemimpinan yang baik, yaitu dengan memanfaatkan atau menggerakkan sumber-sumber yang tersedia, salah satunya adalah sumber daya manusia agar tetap loyal, untuk meningkatkan kinerjanya diperlukan kepemimpinan yang baik. Manajemen Sumber Daya Manusia secara implisit menyamakan manusia dengan benda yang dapat diatur dan dikelola tidak sepenuhnya salah, tetapi ini mereduksi hakekat kemanusiaan menjadi sekedar mahkluk yang berdimensi fisik serta mengabaikan dimensi lainnya seperti sosial emosional, mental dan spiritual. Ketiga dimensi terakhir disebut ini hanya bisa didekati dengan kepemimpinan.

Peningkatan kinerja karyawan dapat tercapai apabila perusahaan/instansi mampu memberikan motivasi terhadap kinerja karyawan untuk membentuk iklim kerja yang baik sehingga terbentuk kinerja yang tinggi. Memberikan motivasi adalah pekerjaan yang dilakukan oleh seorang pemimpin/manager dalam memberikan inspirasi, semangat dan dorongan kepada orang lain untuk mengambil tindakan.

B. Rumusan Masalah

1. Apa pengertian motivasi dan kepemimpinan?

2. Apakah motivasi berpengaruh terhadap kinerja karyawan?

3. Apakah kepemimpinan berpengaruh terhadap kinerja karyawan?

4. Apakah kepemimpinan dan motivasi kerja secara bersama-sama berpengaruh terhadap kinerja karyawan? 


\section{BAB II}

\section{PEMBAHASAN}

\section{A. Definisi Motivasi dan Kepemimpinan}

Kepemimpinan menurut Ralph M. Stogdill (Wahjosumidjo 2004) didefinisikan sebagai sarana pencapaian tujuan yang dimaksudkan dalam hubungan ini pemimpin merupakan seseorang yang memmiliki suatu program dan yang berperilaku secara bersama-sama dengan anggotaanggota kelompok dengan mempergunakan cara atau gaya terentu. Sehingga kepemimpinan mempunyaui peranan sebagai kekuatan dinaik yang mendorong, memotivasi dan mengkoordinirkan organisasi dalam mencapai tujuan yang telah ditetapkan.

Kepemimpinan adalah kemampuan para pemimpin mempengaruhi para bawahannya sehingga para bawahannya bersedia secara sukarela melaksanakan pekerjaan sesuai dengan keinginan pemimpinnya. Kepemimpinan dapat diartikan sebagai kemampuan mendorong sejumlah orang (dua orang atau lebih) agar bekerja sama dalam melaksanakan kegiatan-kegiatan yang terarah pada tujuan bersama.

Organisasi merupakan suatu perkumpulan orang yang memilki tujuan bersama untuk memenuhi kebutuhan hidupnya. Perilaku organisasi merupakan pembelajaran tentang suatu sifat/karakteristik individu yang tercipta di lingkungan suatu organisasi. Karena manusia berbeda - beda karakteristik, maka perilaku organisasi berguna untuk mengetahui sifat sifat individu dalam berkinerja suatu organisasi. Pembelajaran perilaku organisasi akan mengetahui tentang cara - cara mengatasi masalah masalah yang ada di lingkungan organisasi.

Dewasa ini terdapat bermacam-macam teori tentang kepemimpinan yang di dalamnya terdapat perbedaanperbedaan dalam pendapat dan metologi-metologi, keterangan dan kesimpulan. Ada beberapa macam teori-teori kepemimpinan menurut Stephen P. Robbins (2008) : 
Teori Perilaku (Behavioral Theory) Kepemimpinan mempunyai kemampuan untuk Berdasarkan bukti yang ada, teori perilaku seperti halnya teori sifat, member tambahan pemahaman mengenai kepemimpinan yang efektif. Pra pemeimpi yang memiliki sifat-sifat tertentu dan yang menampilkan perilaku tenggang rasa (consideration) dan disiplin dalam kerja (structuring) memang lebih efektif.

Teori Situasional Hersey dan Blanchard, Paul Hersey dan Ken Blanchard telah mengembangkan sebuah model kepemimpinan yang memperoleh banyah pengikut setia di kalangan spesialis pengembangan manajemen. Model ini disebut teori kepemimpinansituasional (situasionla leadership theory). Kepemimpinan situasional adalh sebuah teori yang kemungkinan berfokus pada para pengikut. Kepemimpinan yang berhasil dicapai dengan cara memilih gaya kepemimpinan yang benar. Penekanan pada para pengikut dalam efektivitas kepemimpinan mencerminkan realitas bahwa para pengikutlah yang menerima atau menolak pemimpin tersebut. Pada dasarnya SLT menganggap hubungan pemimpin dengan pengikut dapat disamakan dengan hubungan antara orang tua dan anak di dalam keluarga. Seperti contoh orang tua melepaskan kendali mereka ketika anak sudah menjadi leih dewasa dan bertanggung jawab.

Teori Pertukaran Pemimpin dan Anggota, Teori ini menyatakan bahwa karena tekanan waktu, pemimpin membangun suatu hubungan khusus dengan kelompok kecil dari para pengikutnya. Mereka membentuk kelompok baru dengan anggota yang dipercaya. Mereka mendapatkan lebih sedikit waktu dari pemimpin, lebih sedikit penghargaan dan memiliki hubungan yang didasarkan pada interaksi formal.

Teori Jalan-Tujuan (path-goal theory), Teori ini merupakan tugas pemimpin untuk memberikan informasi, dukungan, atau sumber-sumber daya lain yang dibutuhkan kepada para pengikut atau bawahan agar mereka bisa mencapai berbagai tujuan mereka. Istilah jalan-tujuan berasal dari keyakinan bahwa para pemimpin yang efektif semestinya bisa 
menunjukan jalan guna membantu pengikut-pengikut mereka untuk mendapatkan hal-hal yang mereka butuhkan demi mencapai tujuan kerja dan mempermudah perjalanan serta menghilangkan berbagai rintangannya.

\section{B. Motivasi tergadap kinerja karyawan}

Hasibuan (2008), motivasi adalah pemberian daya pengerak yang menciptakan kegairahan seseorang agar mereka mau bekerja sama, bekerja efektif dan terintegrasi dengan segala daya upayanya untuk mencapai kepuasan. Jadi motivasi mempersoalkan bagaimana caranya mengarahkan daya dan potensi bawahannya, agar mau bekerja sama secara produktif, berhasil mencapai dan mewujudkan tujuan yang telah ditentukan. Pentingnya motivasi karena motivasi adalah hal yang menyebabkan, menyalurkan, dan mendukung perilaku manusia, supaya mau bekerja giat dan antusias mencapai hasil yang optimal.

Motivasi menurut Hasibuan (2008) adalah pemberian daya gerak yang menciptakan kegairahan kerja seseorang agar mereka mau bekerjasama, bekerja efektif dan terintegrasi dengan segala upayanya untuk mencapai kepuasan.

Motivasi adalah keadaan dalam pribadi seorang yang mendorong keinginan individu melakukan kegiatan-kegiatan tertentu untuk mencapai tujuan Buhler, (2004) memberikan pendapat tentang pentingnya motivasi sebagai berikut : "motivasi pada dasarnya adalah proses yang menentukan seberapa banyak usaha yang akan dicurahkan untuk melaksanakan pekerjaan. Motivasi atau dorongan untuk kerja ini sangat menentukan bagi tercapainya sesuatu tujuan, maka manusia harus dapat menumbuhkan motivasi kerja setinggi-tingginya bagi karyawan dalam perusahaan.

Pengertian motivasi erat kaitannya dengan timbulnya sesuatu kecenderungan untuk berbuat sesuatu guna mencapai tujuan. Ada hubungan yang kuat antara kebutuhan motivasi, perbuatan, atau tingkah laku, tujuan dan kepuasan. Karena setiap perubahan senantiasa berkat 
adanya dorongan motivasi. Motivasi timbul karena pencapaian tujuan tertentu. Apabila tujuan telah tercapai maka akan tercapai kepuasan dan cenderung untuk diulang kembali sehingga lebih kuat dan mantap.

Hirarki kebutuhan menurut maslow (Robbins, 2008) bahwa motivasi didasarkan atas tingkat kebutuhan yang disusun menurut prioritas kekuatannya.

Apabila kebutuhan pada tingkat bawah telah dipenuhi maka kondisi ini menimbulkan kebutuhan untuk memenuhi perilaku yang menuntut kebutuhan yang lebih tinggi. Tingkat kebutuhan terbawah adalah kebutuhan fisiologis atau kebutuhan untuk hidup terus misalnya kebutuhan untuk makan, tidur, udara dan sebagainya. Setelah kebutuhan tersebut terpenuhi, maka kebutuhan selanjutnya adalah kebutuhan keselematan dan keamanan.

Dalam mengukur tingkat motivasi kerja anggota, indicator yang akan diteliti adalah perilaku anggota yang mencerminkan motivasi mereka dalam melakukan pekerjaan yang meliputi : kesungguhan dan keseriusan dalam meyelesaikan pekerjaan tanggung jawab terhadap diri sendiri, atasan dan sesame anggota, kebutuhan akan prestasi dan hasil kerja yang baik : ketabahan akan kejujuran dalam bekerja dan keuletan atau kekhawatiran jika menghadapi kegagalan.

Motivasi merupakan satu penggerak dari dalam hati seseorang untuk melakukan atau mencapai suatu tujuan. Motivasi juga bisa dikatakan sebagai rencana atau keinginan untuk menuju kesuksesandan menghindari dari kegagalan dalam kehidupan. Dengan kata lain motivasi adalah sebuah proses untuk mencapai suatu tujuan. Seseorang yang mempunyai motivasi berarti ia telah mempunyai kekuatan untuk memperoleh kesuksesan dalam kehidupan.

Motivasi dapat berupa motivasi intrinsic dan ekstrinsic. Motivasi yang bersifat intrinsic adalah mana kala sifat pekerjaan itu sendiri yang 
membuat seorang termotivasi, orang tersebut kepuasan dengan melakukan pekerjaan tersebut bukan karena rangsangan lain seperti status ataupun uang atau bisa juga dikatakan seorang melakukan hobbynya. Sedangkan motivasi ekstrinsik adalah manakala elemen elemen diluar pekerjaan yang melekat di pekerjaan tersebut menjadi factor utama yang membuat seorang termotivasi seperti staus ataupun kompensasi.

\section{Kepemimpinan terhadap kinerja keryawan}

Pengertian kinerja dalam bahasa Indonesia dari kata dasar "kerja" yang menterjemahkan kata dari bahasa asing prestasidan bisa juga diartikan sebagai hasil kerja. Pengertian kinerja dalam organisasi merupakan jawaban dari berhasil atu tidaknya tujuan organisasi yang telah ditetapkan.

Kinerja karyawan adalah hasil yang dicapai karyawan dengan adanya kemampuan dan perbuatan dalam situasi dan periode tertentu menurut Hukuran yang berlaku untuk pekerjaan yang bersangkutan. Menurut Anwar Prabu Mangkunegara (2005) kinerja (Prestasi Kerja) adalah hasil kerja secara kualitas dan kuantitas yang dicapai oleh seorang karyawan dalam melaksanakan tugasnya sesuai dengan tanggung jawab yang diberikan kepadanya.

Menurut Martoyo, (2007), kinerja karyawan adalah hasil kerja selama periode tertentu dibandingkan dengan berbagai kemungkinan, misalnya standart, target/sasaran atau criteria yang telah disepakati bersama. Kinerja adalah hasil yang diinginkan dari perilaku kinerja individu merupakan dasar dari kinerja organisasi. Penilaian kinerja mempunyai peranan penting dalam peningkatan motivasi ditempat kerja. Penilaian kinerja ini (performance appraisal) pada dasarnya merupakan factor kunci guna megembangkan suatu organisasi secara efektifdan efesien. Karyawan menginginkan dan memerlukan balikan berkenaan dengan prestasi mereka jika kinerja tidak sesuai dengan standart,maka penilaian memberikan kesempatan untuk meninjau kemajuan karyawan dan untuk 
menyusun rencana peningkatan kinerja.

Hasibuan (2001) mengemukakan " kinerja (prestasi kerja) adalah suatu hasil kerja yang dibebankan kepadanya yang didasarkan atas kecakapan, pengalaman dan kesungguhan serta waktu. Menurut Veizal Rivai (2004) mengemukakan kinerja adalah : " merupakan perilaku yang ditampilkan setiap orang sebagai prestasi kerja yang dihasilkan oleh karyawan sesuai dengan perannya dalam perusahaan", Menurut Robert L. Mathis dan John H. Jakcson terjemahan Jimmy Sadeli dan Bayu Prawira (2002) menyatakan bahwa "Kinerja pada dasarnya adalah apa yang dilakukan dan tidak dilakukan karyawan". Kata kinerja (performance) dalam konteks tugas, sama dengan prestasi kerja. Para pakar banyakmemberikan definisi tentang kinerja secara umum, dan dibawah ini disajikan beberapa diantaranya :

Kinerja adalah catatan tentang hasil-hasil yang diperoleh dari fungsifungsi pekerjaan atau kegiatan tertentu selama kurun waktu tertentu. Kinerja adalah Keberhasilan sesorang dalam melaksanakan suatu pekerjaan. Kinerja mengandung dua komponen penting yaitu :

a. Kompetensi berarti individu atau organisasi memiliki kemampuan untuk mengidentifikasikan tingkat kinerjanya.

b. Produktifitas : Kompetensi tersebut diatas dapat diterjemahkan ke dalam tindakan atau kegiatankegiatan yang tepat untuk mencapai hasil kinerja (outcome).

Ada 5 (lima) factor dalam penilaian Kinerja yaitu :

a. Kualitas pekerjaan meliputi: akuisi, ketelitian, penampilan dan penerimaan keluaran;

b. Kuantitas pekerjaan melipui : Volume keluaran dan kontribusi;

c. Supervisi yang diperlukan, meliputi : membutuhkan saran, arahan atau perbaikan;

d. Kehadiran meliputi : regularitas, dapat dipercaya diandalkan dan 
ketepatan waktu;

e. Konservasi meliputi : pencegahan, pemborosan, kerusakan dan pemeliharaan.

Ada 3 (tiga) factor yang berpengaruh terhadap kinerja seseorang antara lain :

a. Faktor individu : kemampuan, ketrampilan, latar belakang keluarga, pengalaman tingkat social dan demografi seseorang;

b. Faktor psikologis : persepsi, peran, sikap, kepribadian, motivasi dan kepuasan kerja;

c. Faktor organisasi : struktur organisasi, desain pekerjaan, kepemimpinan, system penghargaan (reward system).

Penilaian kinerja (performance appraisal pada dasarnya merupakan factor kunci guna mengembangkan suatu organisasi secara efektif dan efesien, karena adanya kebijakan atau program yang lebih baik atas sumber daya manusia yang ada dalam organisasi. Penilaian kinerja individu sangat bermanfaat bagi dinamika pertumbuhan organisasi secara keseluruhan, melalui penilaian tersebut maka dapat diketahui kondisi sebenarnya tentang bagaimana kinerja karyawan. Penilaian kinerja adalah cara mengukur kontribusi individu (karyawan) kepada organisasi tempat mereka bekerja.

D. Pengaruh kepemimpinan dan motivasi kerja terhadap keryawan 


\section{BAB III}

\section{PENUTUP}

\section{A. Kesimpulan}

Kepemimpinan berpengaruh signifikan terhadap Motivasi Kerja. Kompensasi berpengaruh signifikan terhadap Motivasi Kerja.Kepemimpinan berpengaruh signifikan terhadap Kepuasan Kerja Kompensasi berpengaruh tidak signifikan terhadap Kepuasan Kerja. Motivasi Kerja berpengaruh tidak signifikan terhadap Kepuasan Kerja. Kepemimpinan bepengaruh secara langsung terhadap Kepuasan Kerja tanpa dimediasi oleh Motivasi Kerja. Kompensasi berpengaruh secara langsung terhadap Kepuasan Kerja tanpa dimediasi oleh Motivasi Kerja.

B. Saran

Berdasarkan kesimpulan diatas maka saran-saran yang dapat diberikan pada penelitian ini antara lain adalah kepemimpinan yang baik diharapkan dapat lebih tegas lagi dalam mengambil keputusan dan memberikan dorongan dan semangat kerja kepada karyawan serta bertanggung jawab setiap ada permasalahan. Kompensasi yang diberikan perusahaan seharusnya sesuai dengan beban kerja karyawandan latar belakang pendidikan serta diberikan secara adil.Motivasi kerja sebaiknya lebih dipertahankan agar karyawan teliti dalam melakukan pekerjaan. Kepuasan kerja karyawan perlu diperhatikan lagi agar prestasi kerja karyawan dapat meningkat.

DAFTAR ISI 